\title{
Evaluating Bank Cost Efficiency Using Stochastic Frontier Analysis
}

\author{
Sanderson Abel ${ }^{1}$, Alex Bara ${ }^{2}$, Pierre Le Roux ${ }^{3}$ \\ ${ }_{1}^{1}$ Department of Agricultural Economics, Midlands State University, Zimbabwe \\ ${ }^{2}$ Agricultural Bank of Zimbabwe, Zimbabwe \\ ${ }^{3}$ Department of Economics, Nelson Mandela University, South Africa \\ alexbara15@gmail.com
}

\begin{abstract}
The study seeks to assess the cost efficiency of the commercial banks in Zimbabwe using the stochastic frontier analysis. The cost efficiency of the Zimbabwean banks is estimated using the trans-log stochastic frontier approach. The Stochastic Frontier Analysis methodology is among the host of methods that has been used to measure banking sector efficiency. The analysis of cost efficiency of commercial banks has important implications for the economy since an efficient banking system has potential to reduce interest rates which can lead to increased investment and growth for the economy. The cost of doing business in Zimbabwe is perceived to be high hence improved bank efficiency has the potential to reduce the cost of doing business. The average cost efficiency scores for the Zimbabwean banks over the study period show that the banking sector in Zimbabwe experiencing 17 percent inefficiency. The efficiency levels have been declining over the years reflecting increased resource wastage in the system. The study recommends that the banking institutions should continue to innovate so as to reduce their inefficiencies.
\end{abstract}

Keywords: Commercial Banks, Cost Efficiency, Stochastic Frontier Analysis, Zimbabwe.

\section{Introduction}

In recent times there has been a proliferation of studies in bank efficiency (Abel, Bara, \& Le Roux, 2018), (Okoire \& Agu, 2015), (Kofi, Gan, \& Hu, 2014), (Ngan, 2014), (Hasan, Kamil, Mustafa, \& Baten, 2012), (Manlagñit M. C., 2011). (Berger \& Mester, 1997), notes the interest in banking sector efficiency emanates from the structural changes taking place in both the financial and non-financial sectors coupled with the adoption of technologies in the provision of financial services. Efficiency measurements are being used as proxies to measure innovativeness of managers and their ability to contain expenditures while maximising payoffs i.e. income and profit. It follows therefore that institutions are interested in pursuing activities that lead to the realisation of planned objectives but also assure more gains from less inputs. The concept of efficiency in economics has been analysed from an economic and organization theory perspective. Efficiency can be defined broadly as the application of minimum resources in the production of maximum output. Institutions are interested in producing maximum output using limited resources. Institutions that are able to produce more output given a limited amount of resources are perceived to be more efficient as compared to one that produces less output. The concept of efficiency has been expanded outside the realm of welfare economics to other related economic disciplines such as banking, finance and health economics among other.

(Farrel, 1957), is credited with introducing the subject of efficiency in the economic discourse. Efficiency is made up of two parts, technical and allocative efficiency (Farrel, 1957). Technical efficiency is a measure of the extent to which a decision-making unit is able to minimise resources in the production of a given level of output. Allocative efficiency evaluates a decision-making unit ability to apply resources during the production process in optimal proportions given the prices and state of production technology. Technical efficiency combined with allocative efficiency provides a measure of total efficiency (Coelli, 1998). Efficiency measurement contains both macroeconomic and microeconomic implications (Berger \& Mester, 1997). Microeconomic studies shows that bank efficiency is a product of the level of competition which emanates from the entry and exit of foreign banking institutions in the domestic market, improvement in the regulatory environment and changes in institutional frameworks over time (Koutsomanoli-Filippaki, Margaritis, \& Staikouras, 2009). On a macroeconomic scale banking sector efficiency reduces the cost of banking and improves the strength of the system (Rossi, Schwaiger, \& Winkler, 2005). This is mostly a result of the linkage between the financial system and the productive sector which draws resources from the earlier.

An efficient banking system leads to enhanced resource allocation in favour of projects that are growth improving (Andrie \& dan Cocri, 2010). Despite increased research on banking efficiency, there has not been 
much consensus on the results generated (Brack \& Jimborean, 2010). The differences among the various studies has been a result of differences in economic conditions in the different countries, methods and mechanism used to regulate institutions as well as supervisory regimes. In country differences have been attributed to the magnitude of competition among financial players, differences in product offering in terms of quality and the level of development in the financial markets (Brack \& Jimborean, 2010). The current study evaluates the commercial bank cost efficiency in Zimbabwe using the stochastic frontier analysis. There have not been more studies that have focused on the performance of the Zimbabwean banking system (Abel, S. 2018) (Abel, Bara, \& Le Roux, 2018) to the author's knowledge and the majority of them employed the data envelopment method. In divergence with the previous studies the current one will use the parametric method of stochastic frontier analysis.

A study like this one has important implications for the country for a number of reasons; an efficient banking system has potential to reduce interest rates which can lead to increased investment and growth for the economy. Secondly, the cost of doing business in Zimbabwe has been perceived to be too high hence improved efficiency has the potential to reduce the same. The government of Zimbabwe has been interfering in the setting of interest rates through controls hence such study can help justify or dispel the government's action. The study is organised in the following manner; in section 2, the study discusses the developments in the banking sector. The literature review is presented in section 3. The methodology will be discussed in section 4 followed by presentation of results. In section 5 conclusions and recommendations of the study are discussed. There have been a number of innovative developments by banks which has been experiencing a lot of pressure from competition coming from both the banking and no banking sector. Banks were coerced into pursuing aggressive growth strategies driven by deposit mobilisation, strategic partnerships and investment in digital platforms.

Developments in the Banking Sector in Zimbabwe: The Zimbabwe economy has transformed significantly from the hyperinflationary periods of 2008 to date. The banking sector has been witnessing great transformation as a result of the low inflation rates between 2009 and 2017. The non-bank financial system has been exerting a lot of pressure on the banking sector especially mobile money. To counter competition from the mobile money service providers the banks have been innovative which included partnering the mobile network operators. In December 2016, all banks had partnered with the biggest mobile network operator (Econet) on its ecocash platform. Some of the banks had also partnered with other smaller MNOs. The partnership became handier for banks as the economy experienced cash challenges hence the majority of the transactions were being facilitated through mobile money. During the study period there was a proliferation of new product by banks as they tried to wither competition. New products or customer made products such mortgage financing, money transfer agency business, bill payments, as well as various products targeted at farmers and SMEs. These new products were mostly meant to increase the sources of bank income in light of tight competition from fellow banks and non-bank financial institutions. Partnering money transfer agents and mobile services providers was meant to harness resources coming from the diaspora, a growing foreign currency cash cow for the country whose diaspora population is quite significant.

The banks were also affected by exogenous shocks hence rendered banks to become aggressive in preserving their markets. The banking sector experienced closure of many correspondent relationships during the period. As a result of derisking, most correspondent banks were forced to close accounts that were held by Zimbabwean banks. This then handicapped the banks from undertaking foreign payments and receiving remittances from abroad. This further compromised the banks' ability to source foreign lines of credit which are critical for the resuscitation of the ailing economy. The closure of correspondent relationships forced the banks to circumvent this challenge through the use of third-party banks or use alternative currency for foreign currency payments though this could be expensive alternative. The banks also experienced challenges with a situation where the Central Bank also became more of a player. The Central Banks become involved in financing the productive sector hence directly competing with commercial as well as other financial players. The central bank was involved in financing tobacco, horticulture, small scale miners, among others. This brought direct competition between the central bank and banks leading to financial disintermediation as commercial banks were by passed in the credit allocation. These central bank financing facilities were cheaper than commercial banks leading disintermediation. In another form of financial disintermediation, the 
central bank on behalf of the government was involved in private placement of treasury bills against international best practice.

Figure 1: Average Weighted Bank Lending Rates for Corporates and Individuals

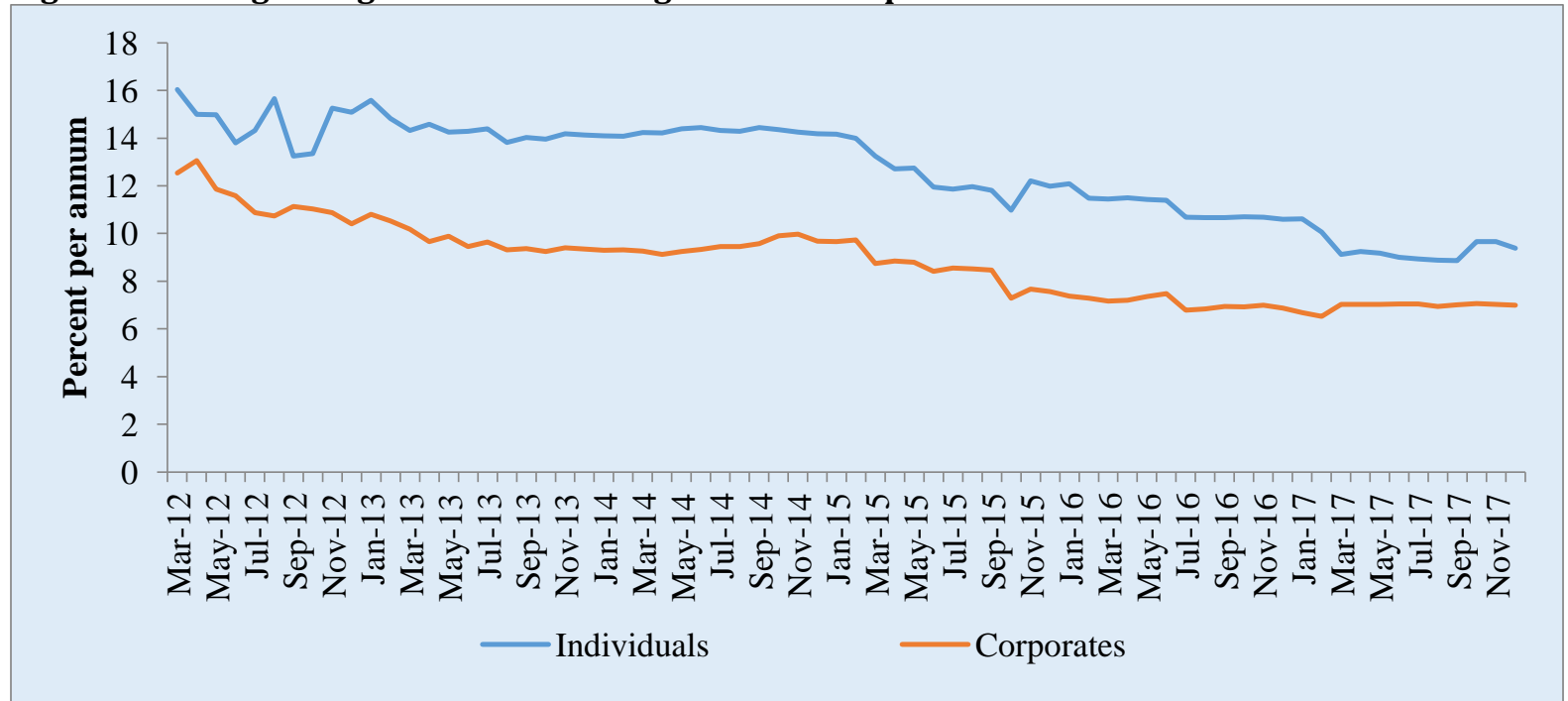

Source: RBZ, 2017

The central bank is heavily involved in the pricing of the banking product especially productive sector facilities. This intervention is a form of pricing controls on the banks as it involves dictating the maximum allowable interest rates and charges to be charged on loans and services. The interest rates have gradually been revised down from $18 \%, 15 \%$ and $12 \%$ for the productive sectors without market-based justification. The whole situation shows that the financial system has reverted back to periods of financial repression since market forces are no longer applicable in the determination of the interest rates (Figure 1). Given the controls that were placed on lending rates, banks were forced to go for treasury bills at the expense of lending to the productive sector. This then led to the crowding out effect. Banks suffered as their business models were distorted as a result of financial repression. The regulating of pricing distorts the business models because the caps on service charges and lending rates fail to absorb the cost of funds. This then compromised the ability of the banks to seek external lines of credit as most potential lenders believe in the markets determining pricing. On the other hand banks had acquired lines of credit based on prevailing interest rates hence the move of the central bank only led to situations where banks had to cut down on their margins. As a result of the caps on lending banks adopted a conservative approach to lending hence affecting the productive sectors of the economy.

\section{Figure 2: Commercial Banks Holding of TBs and Private Credit}

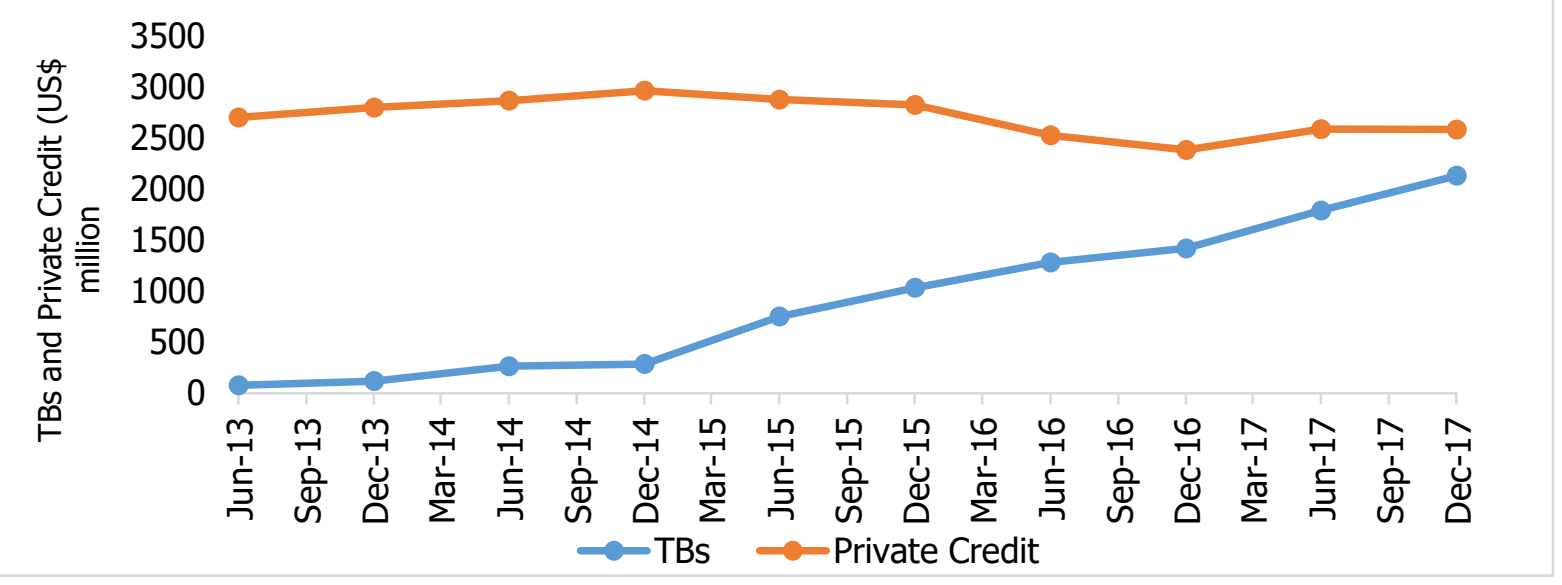


The combined effect of reduced interest rates and the increased Treasury Bills issuance by the government forced banks to abandon lending to individuals and corporates preferring to hold public debt perceived to be risk free (Figure 2). This was further worsened by the fact that the margin between the lending rates and the government paper was declining over time hence the preference of the later by the banks. Banks were therefore finding a safe haven in TBs which are a relatively less risky investment. The justification for such a move by the banks is that the interest rates are low to cushion them from the risk prevailing in the market hence better to hold relatively less risky assets. In light of the increased issuance of government paper on the market, the bank's assets were increasingly being composed of TBs. This was a signal of the increased dominance of the government paper against lending to corporates and individuals. This then compromises the banks ability to source resources offshore if they have a balance sheet tilted towards government paper. Banks would then need to strongly justify such lines of credit where these resources are likely not to be applied to the productive sector. The study evaluates the cost efficiency of the banking sector using a parametric technique of stochastic frontier method.

\section{Literature Review}

This section reviews studies that have been done by other scholars on bank efficiency. The studies will direct the current paper on the various discussion, methodologies and results used in prior studies. The section concentrates mostly on studies that have used the methods of data envelopment analysis and stochastic frontier analysis (Abel, 2018) (Abel, Bara, \& Le Roux, 2018) (Okoire \& Agu, 2015) (Kofi, Gan, \& Hu, 2014) Kofi (Ngan, 2014), (Hasan, Kamil, Mustafa, \& Baten, 2012), and (Manlagñit M. C., 2011). The literature review will assist in drawing conclusion and comparisons in the succeeding sections. (Khalil, Mehmood, \& Ahmad, 2015), evaluated the cost efficiency of the Pakistan's banking using a transcendental logarithmic (translog) cost frontier using quarterly panel data. The aim of the study was determine the level of efficiency in the Pakistan banking sector for the period 2005-2013. The authors found that banks in Pakistan had enough scope to improve their efficiency levels through maximising output by adopting either a diversification or cost containment approach. The cost of banking could be reduced through a reduction in the prices of inputs. Employing the same method of stochastic frontier analysis, (Ngan, 2014) assessed the cost and profit efficiency of banks in Vietnam spanning the period 2007-2012. The results revealed mixed results which showed that local institutions were cost efficient while foreign ones were profit efficient. Cost efficiency was found to be closely related to bank concentration, mergers and bank ownership.

(Manlagñit M. C., 2011), evaluated the relationship between risk and bank efficiency of the Philippine commercial banks for the period 1990-1999. The results revealed that the 1997 financial crisis had a negative and significant impact on banking sector cost efficiency. The regulatory reform that was instituted in Philippine has the effect of strengthening the banking sector. The cost efficiency was negatively affected also by mergers and acquisitions. Applying a 2 step estimation technique, (Montgomery, 2014) studied the cost and profit efficiency of the Japanese banking system during the period 1996 - 2009. The findings from the study indicated that bank mergers had a positive effect on both profit and cost efficiency. (Hasan, Kamil, Mustafa, \& Baten, 2012), applied the stochastic frontier analysis to measure the technical efficiency of the Malaysian banks listed on stock market. The sample was drawn from only those banks that were listed for the period between 2005 and 2010. The technical efficiency score was found to be 94 percent reflecting a 6 percent level of wastage. The study period exhibited an overall upward trend in technical efficiency characterised by wide considerable fluctuations. (Kristo, 2013), adopted a mixed method approach in assessing the efficiency of the Albanian banks. The approaches employed included the traditional approach as well as the stochastic frontier analysis. The traditional approach revealed that efficiency was declining in the Albanian banking sector. The stochastic frontier approach showed that the big banks tended to be more efficient compared to small bank.

The results of the study did not show any noticeable effect of return on assets and size on the cost efficiency scores. In a study of 12 Central and Eastern European countries for the period 1993-2000, (Semih Yildirim \& Philippatos, 2007) applied both the stochastic frontier and DFA methods to measure bank efficiency. The study adopted loans, investments and deposits as inputs. Borrowed funds, labour and physical capital were the outputs used. The SFA and DFA scores were 77 percent and 72 percent respectively. They further established that Poland and Slovenia were the most efficient countries among the countries studied. Using the 
same method, (Yan, X, \& J, 2009) assessed the implication of ownership as well as the implementation of hard budget constraint on the efficiency of banks. The study established that non-state banks were more efficient as compared to state banks with a margin of 8-18 percent. The study revealed that banks that relied on government funding were less efficient compared to those that experienced hard budget constraints. Employing the fixed effect and dynamic generalised method of moments, (Kofi, Gan, \& Hu, 2014) evaluated the efficiency of the Ghana banking industry. The study showed that Ghana's banking sector is inefficient. The study further revealed that banks that were adequately capitalised were not efficient. Size and loan loss provision was found to be insignificant in determining efficiency. Larger banks were equally inefficient as the smaller banks.

The study found cost efficiency persistence among banks where efficiency was increasing over time. (Abel S., 2018), studied the cost efficiency of commercial banks in Zimbabwe during the period the 2009-2014. The study used the data envelopment analysis and Tobit regression method. The study revealed that banks in Zimbabwe experienced an average inefficiency level of 19 percent. The significant determinants of efficiency were found to be profitability, capital adequacy, bank size, credit risk and economic stability. A stable macroeconomic environment was found to be important for financial institutions to improve their cost efficiency. (Abel, Bara, \& Le Roux, 2018; Abel, Bara, \& Le Roux, 2018; Abel, Bara, \& Le Roux, 2018), decomposed the technical efficiency of the banking sector into pure technical and scale efficiency of the Zimbabwean banking sector using the data envelopment analysis. The study sample consisted of domestic and foreign banks. The average bank efficiency was found to be 82.9 percent, while pure technical efficiency and scale efficiency were 96.6 percent and 85.6 percent respectively. Decreasing returns to scale was found to be the main reason for the scale inefficiency. Zimbabwean banks are hence operating below their optimum capacity with greater room to improve on their efficiency levels. Decomposing time periods into preconsolidation and post consolidation, (Okoire \& Agu, 2015) assessed the effect of reforms on the Nigerian banks performance and efficiency using the data envelopment analysis method. The study found that the two time periods exhibited differences in efficiency. The reforms improved the efficiency of the majority of the banks with a few remaining inefficient.

Consolidation was found not to be the reason behind improved efficiency since some banks remained inefficient after the process. The Nigerian banking system was not spared by the effects of the global financial crisis. (Nazir \& Alam, 2010), used data envelopment analysis to measure the effect of financial restructuring on the Pakistan banks performance for the period 2003-2007. The aim of the research was to determine the operating efficiency of the Pakistan commercial banks. The result showed that there was no improvement in banking efficiency as a result of privatisation. The study further shows that public banks could do better by covering their interest and non-interest expense from their corresponding revenues. In a study on the efficiency of the domestic banks in Pakistan, (Ahmed, S, \& H, 2009) used the data envelopment analysis and the malmquist index for the period 1990 - 2005. The study further assessed the effect of financial sector reforms on the banking sector. The results confirmed that financial sector reforms improved the domestic commercial banks efficiency. (Olaosebikan, 2009), studied the effect of the introduction of the minimum capital requirements on bank efficiency in Nigeria. The study covered the period 1999-2005 and took into consideration the pre and post introduction of minimum capital requirements in the banking sector and used the data envelopment analysis as well as the Tobit method to evaluate efficiency. The study showed that there was a decline in the number of institutions in distress as a result of the reforms introduced in the late 1990s. The banking sector was strengthened and became less volatile as result of consolidation and introduction of minimum capital requirements.

\section{Methodology}

The study employs the stochastic frontier analysis methodology. (Aigner, C. \& P), and (Meeusen \& van den Broeck, 1997) are credited with the development of the stochastic frontier approach independently. The Stochastic frontier approach is a stochastic method which incorporates random errors. The functional form of the model needs to be defined in advance. The output of a company is a function of inputs, inefficient and random errors which are predefined as well as the error term distribution. The SFA method allows the modelling of factors which could impact an organisation but not controllable by the same. The above advantages render the Tran slog function more suitable for the evaluation of the banking system premised on 
its multi criteria character. The assumption of linear homogeneity in input prices is imposed by normalising total costs and input prices by one input price. The method achieves this by the introduction of the random error term in the specification of the frontier efficiency model (LR, 2004). Following (Kristo, 2013) and (Ngan, 2014) the general form of the cost frontier model is depicted as follows:

$T C_{i t}=\beta X_{i t}+V_{i t}+U_{i t}$

$i=1,2, \ldots . n ; t=1,2, \ldots, T$

Where

$\mathrm{TC}_{\text {it }}$ Total cost in logarithmic of form in period $t$

$\mathrm{X}_{\mathrm{it}} \quad$ Matrix of outputs, prices and input in logarithmic form

B Vector of unknown parameters

$V \quad$ Random variables which are assumed to be iid $\mathrm{N}\left(0, \delta_{\mathrm{v}}^{2}\right)$ independent of $\mathrm{U}$

$\mathrm{U} \quad$ Non-negative random variables which are assumed to be identically distributed as normal variate and the error term

There are a number of methods that can be used to specify the cost function. These include Cobb Douglas, Leontief, and constant elasticity of substitution, transcendental logarithmic and linear functions. The study uses the transcendental logarithmic (translog) cost function since there is flexibility regarding the stochastic frontier method when a functional form of the translog type functions is used as compared with the Cobb Douglas functions. The translog form also allows data to indicate the real value of the curvature of the function, rather than impose prior hypotheses regarding its value. This type of formulation follows previous studies that have been conducted (Pruteanu-Podpiera, Weill, \& Schobert, 2008), (Kristo, 2013). The empirical model is then outlined as:

$\ln \left[\frac{T C_{i t}}{w_{3 i t}}\right]=\alpha_{0}+\alpha_{1} \ln Y_{i t}+\frac{1}{2} \alpha_{2}\left(\ln Y_{i t}\right)^{2}+\alpha_{3} \ln \left(\frac{w_{1 i t}}{w_{3} i t}\right)+\alpha_{4} \ln \left(\frac{w_{2 i t}}{w_{3 i t}}\right)+\alpha_{5} \ln \left(\frac{w_{1 i t}}{w_{3 i t}}\right) \ln \left(\frac{w_{2 i t}}{w_{3 i t}}\right)+\frac{1}{2} \alpha_{6}\left[\ln \left(\frac{w_{1 i t}}{w_{3 i t}}\right)\right]^{2}+$ $\frac{1}{2} \alpha_{7}\left[\ln \left(\frac{w_{2} i t}{w_{3 i t}}\right)\right]^{2}+\alpha_{8} \ln Y_{i t} \ln \left(\frac{w_{1 i t}}{w_{3 i t}}\right)+\alpha_{9} \ln Y_{i t} \ln \left(\frac{w_{2 i t}}{w_{3 i t}}\right)+\varepsilon_{i t}$

Where:

Y Total loans of a bank

$T C_{\text {it }} \quad$ Total cost of the bank

$w_{1} \quad$ Price of labour

$w_{2} \quad$ Price of physical capital

$w_{3} \quad$ Price of borrowed funds

The study employs the method used by (Battese \& Coelli, 1995) to estimate efficiency scores using the timevarying stochastic frontier approach for panel data with firm effects. The estimations are run using bank fixed effects. For the sake of robustness, the results are compared with those using true random effects stochastic frontier model. The study data is drawn from the financial statement of financial institutions in Zimbabwe. The banking sector in Zimbabwe is composed of twenty financial institutions (14 commercial banks, 4 building societies, a merchant bank and a savings bank). The study only drew data from commercial banks on the basis of completeness of data for the study period (2009-2016) using quarterly data. Before performing any manipulations of the data, the study computes the descriptive statistics. It is important that the econometrics results adhere to certain a priori expectations to avoid spuriousness in the results. The study computes correlation coefficients to ascertain the levels of correlation among variables also. 


\section{Figure 3: Evolution of Efficiency scores}

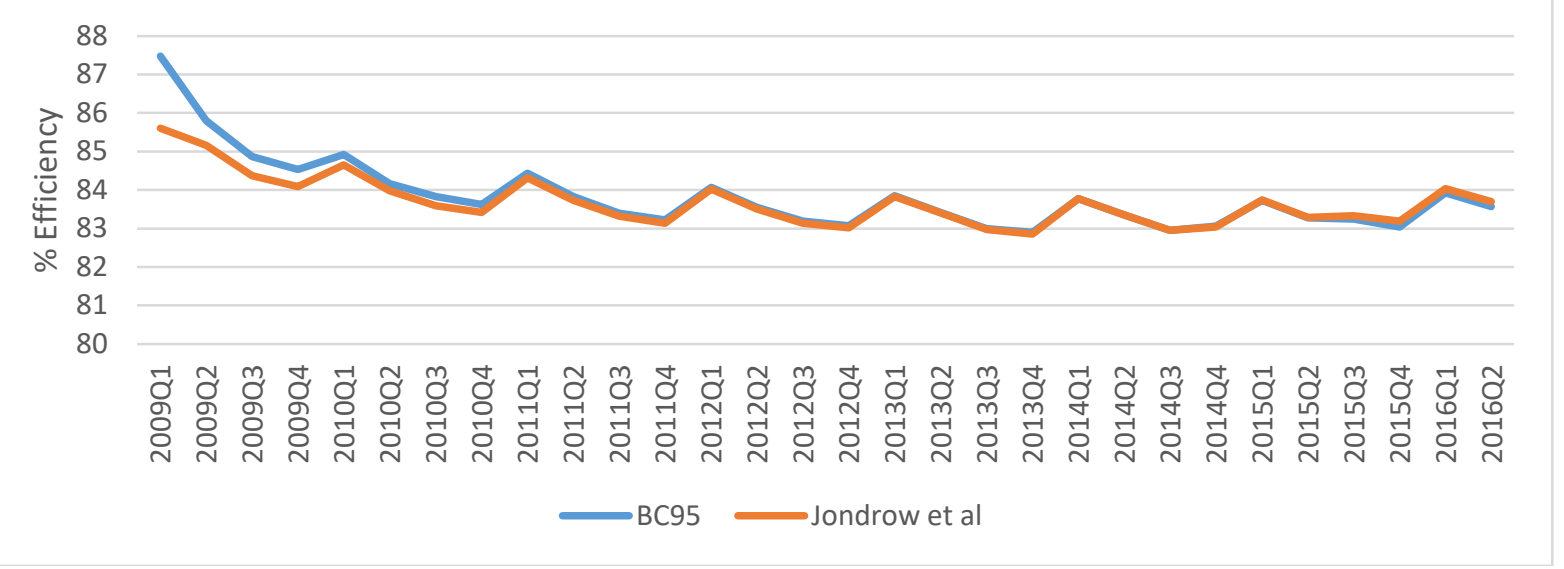

The evolution of the efficiency scores are shown in Figure 3. The efficiency scores declined from an average of 85.6 percent in 2009 quarter 1 to an average of 83.6 percent in 2010 quarter 3 (Figure 3). Since then the average efficiency score has been hovering between 83 percent and 84 percent. The striking issue is the fact that both the scores established by the BC95 model and true random effect model show the same pattern after 2010 quarter 3 with the scores trending together and showing no difference. This is unlike the period between 2009 quarter 1 and 2010 quarter 3 where the BC95 was showing high efficiency scores as compared to the true random effect model. Overall the results augur well with the results obtained in Zimbabwe by other authors using the data envelopment methodology (Abel, 2018) (S \& P., 2018).

\section{Result Presentation and Analysis}

The results of the Trans log function are presented in Table 1 and Table 2. Table 1 is premised on the (Battese \& Coelli, 1995) (BC95) model which is dependent on the fixed effects of the banks.

Table 1: The BC95 Model

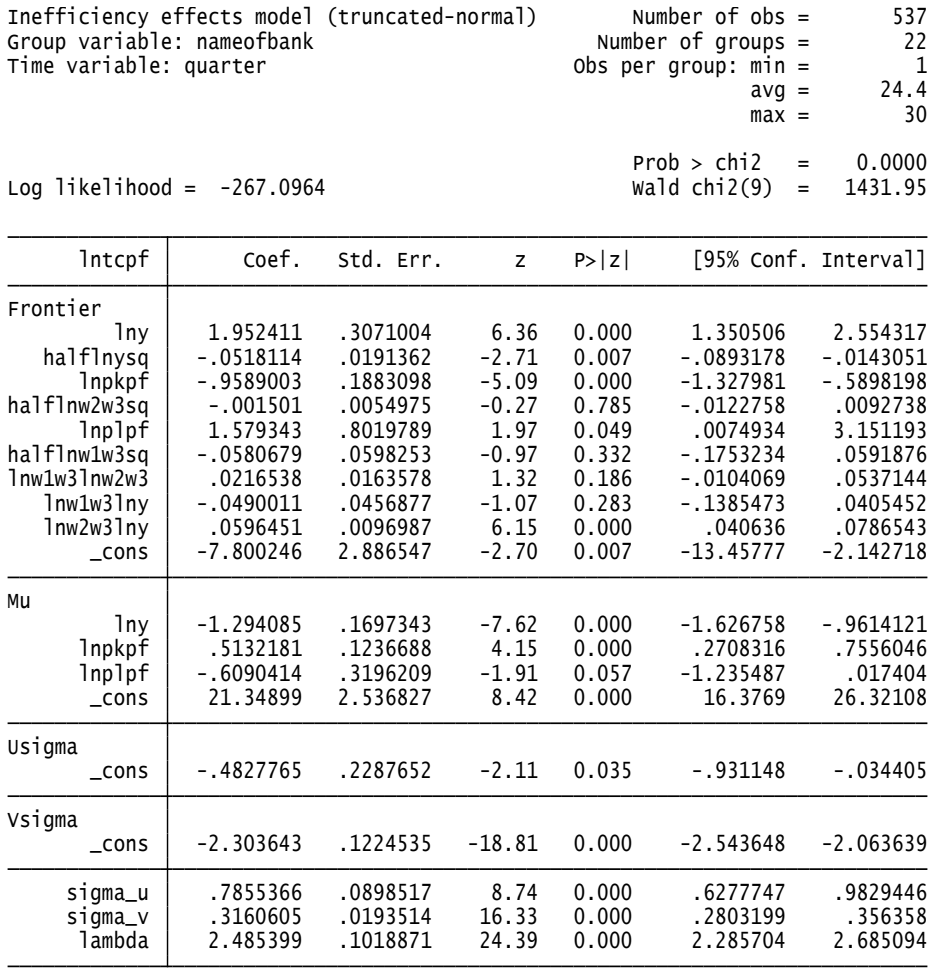


Table 1 presents the estimation of the cost frontier function. The results in the table show that model is correctly fitted and returns correct signs of the estimated coefficients. The coefficient of loans and advances shows that there is a positive relationship between total cost and loans. An increase in loans advanced to bank clients also leads to an increase in total cost. This reflects the fact that banks incur costs as they undertake due diligence on the customers before advancing loans to them. The costs were a bit higher in the Zimbabwean case as the economy did not have a comprehensive credit reference system which meant that banks were supposed to go an extra mile in vetting their clients before actually releasing the loans. The price of labour shows a positive associated with cost. This implies that an increase in price of labour leads to an increase in the total cost of banks. The results are not very surprising for Zimbabwe especially on the labour part where the economy is perceived to be a high cost economy which had been impairing the competitiveness of the economy. The normalised price of capital has a negative effect on the total cost. The results of the BC95 model compares with the results of the true random effects shown in Table 2. This is based on firm-specific efficiency scores as elucidated by Jondrow et al., 1982.

Descriptive Statistics: The average cost efficiency scores for the Zimbabwean banks over the study period is, 83.68 percent using the BC95 model while 83.68 percent using the true random effects model. The average cost efficiency scores for the Zimbabwean banks over the study period is, 83.68 percent using the BC95 model while 83.68 percent using the true random effects model. The two models agree that the average efficiency is around 84 percent indicating that the average bank in the model suffered a 16 percent level of inefficiency compare to the best bank in the sample.

Table 2: True Random Effects SFA Model

$\begin{array}{lrr}\text { True random-effects model (half-normal) } & \text { Number of obs }= & 537 \\ \text { Group variable: nameofbank } & \text { Number of groups }= & 22 \\ \text { Obs per group: } \min = & 1 \\ \text { Time variable: quarter } & \text { avg }= & 24.4 \\ \max = & 30 \\ & \text { Prob }>\text { chi2 }= & 0.0000 \\ \text { Log simulated-likelihood }=-154.6542 & \text { Wald chi2 }(9)= & 1566.59\end{array}$

Number of Randomized Halton Sequences $=50$

Base for Randomized Halton Sequences $=7$

\begin{tabular}{|c|c|c|c|c|c|c|}
\hline Intcpf & Coef. & Std. Err. & $z$ & $P>|z|$ & [95\% Conf & Interval] \\
\hline $\begin{array}{r}\text { Frontier } \\
\text { lny } \\
\text { halflnysq } \\
\text { lnpkpf } \\
\text { half1nw2w3sq } \\
\text { Inplpf } \\
\text { half1nw1w3sq } \\
\text { Inw1w37nw2w3 } \\
\text { lnw1w37ny } \\
\text { lnw2w37ny } \\
\text { _cons }\end{array}$ & $\begin{array}{r}.1655702 \\
.0403908 \\
-.6323551 \\
-.0134373 \\
1.22053 \\
.044137 \\
.0168252 \\
-.012849 \\
.0398232 \\
9.938035\end{array}$ & $\begin{array}{r}.1865883 \\
.0103719 \\
.1717203 \\
.0063503 \\
.4721317 \\
.04696 \\
.0133556 \\
.0286718 \\
.0082826 \\
2.06584\end{array}$ & $\begin{array}{r}0.89 \\
3.89 \\
-3.68 \\
-2.12 \\
2.59 \\
0.94 \\
1.26 \\
-0.45 \\
4.81 \\
4.81\end{array}$ & $\begin{array}{l}0.375 \\
0.000 \\
0.000 \\
0.034 \\
0.010 \\
0.347 \\
0.208 \\
0.654 \\
0.000 \\
0.000\end{array}$ & $\begin{array}{r}-.2001361 \\
.0200623 \\
-.9689208 \\
-.0258837 \\
.2951684 \\
-.0479029 \\
-.0093513 \\
-.0690448 \\
.0235896 \\
5.889063\end{array}$ & $\begin{array}{r}.5312766 \\
.0607192 \\
-.2957895 \\
-.0009908 \\
2.145891 \\
.1361769 \\
.0430018 \\
.0433468 \\
.0560568 \\
13.98701\end{array}$ \\
\hline $\begin{array}{r}\text { Usigma } \\
\text { lny } \\
\text { lnpkpf } \\
\text { Inplpf } \\
\text { _cons }\end{array}$ & $\begin{array}{r}-.7587278 \\
-.142729 \\
-.025385 \\
9.804517\end{array}$ & $\begin{array}{r}.105574 \\
.0566529 \\
.324131 \\
1.631614\end{array}$ & $\begin{array}{r}-7.19 \\
-2.52 \\
-0.08 \\
6.01\end{array}$ & $\begin{array}{l}0.000 \\
0.012 \\
0.938 \\
0.000\end{array}$ & $\begin{array}{r}-.9656491 \\
-.2537666 \\
-.66067 \\
6.606613\end{array}$ & $\begin{array}{r}-.5518066 \\
-.0316914 \\
.6099 \\
13.00242\end{array}$ \\
\hline $\begin{array}{l}\text { Vsigma _cons } \\
\end{array}$ & -2.815893 & .1057376 & -26.63 & 0.000 & -3.023135 & -2.608651 \\
\hline $\begin{array}{l}\text { Theta_cons } \\
\end{array}$ & .2776484 & .0366568 & 7.57 & 0.000 & .2058024 & .3494943 \\
\hline $\begin{array}{r}\text { E(sigma_u }) \\
\text { sigma_v }\end{array}$ & $\begin{array}{l}1.366558 \\
.2446452\end{array}$ & .0129341 & 18.91 & 0.000 & $\begin{array}{r}-.1221066 \\
.220564\end{array}$ & $\begin{array}{r}2.855223 \\
.2713555\end{array}$ \\
\hline
\end{tabular}


Like the BC95 model, the results in the Table 2 shows that the model is correctly fitted and returns correct signs of the estimated coefficients. This is in line with the results of Khalil et al. (2015). The coefficient of loans and advances shows that there is a positive relationship between total cost and loans. The price of labour shows a positive associated with cost. This implies that an increase in price of labour leads to an increase in the total cost of banks. The normalised price of capital has a negative effect on the total cost. The results are similar to those obtained using the BC95 model save for the magnitude of the signs. The true random effect model retaining lower coefficients compared to the BC95 model.

Table 3: Descriptive Statistics of Efficiency Scores

\begin{tabular}{lll} 
& BC95 Model & True Random Effects Model \\
\hline Mean & 83.835 & 83.684 \\
Median & 83.547 & 83.561 \\
Maximum & 97.338 & 89.997 \\
Minimum & 81.680 & 79.280 \\
Standard Deviation & 1.490 & 1.057 \\
Jarque - Bera & 16467.61 & 579.831 \\
Probability & 0.000 & 0.0000 \\
Observations & 540 & 540 \\
\hline
\end{tabular}

According to the BC95 model the minimum efficient score for the sample was 81.7 percent while the maximum score was 97.33. On the other hand, the true random effects model shows that the minimum score was 79.2 percent while the maximum score was 90 percent. The results show that the random effects model compresses downwards the efficient scores as compared to the BC95 model. Despite these differences the two models show that the majority of the scores were above 83.5 percent with both models showing that there are little variations in the scores as indicated by the standard deviation.

\section{Conclusion}

The study sought to investigate the evolution of the banking sector efficiency in Zimbabwe using the Stochastic Frontier Analysis. The SFA methodology is among the host of methods that has been used to measure banking sector efficiency. The analysis of cost efficiency in the commercial banking system of Zimbabwe is an important for the reduction the cost of banking in a country perceived to have high interest rates on lending detrimental to growth. Second the government of Zimbabwe is working on the mechanisms of reducing the cost of doing business of which the perceived high interest rates have been targeted. The intervention by the authorities in the interest rates setting though a major concern calls for an investigation on the efficiency of the banking system. The results show that the banking sector in Zimbabwe experiencing 17 percent level inefficiency score, implying that there are wastages in the banking sector. If this inefficiency is resolved, banks could pass on the reduced cost to their clients in the form of reduced interest rates as well as bank charges and fees. The study recommends that the banking institutions should continue to innovate so as to reduce their inefficiencies.

\section{References}

Abel, S., Bara, A. \& Le Roux, P. (2018). Decomposition of the technical efficiency of the banking system. Journal of Economic and Financial Sciences, 11(1), 1-9.

Abel, S., Bara, A. \& Le Roux, P. (2018). Decomposition of the Technical Efficiency of the Banking System. Journal of Economics and Financial Sciences, 11(1), a160.

Abel, S. (2018). Evaluating the cost efficiency of commercial banks in ZimbabweIssue. MEFMI research and policy journal, (1), 4-25.

Ahmed, U. (2009). Efficiency dynamics and financial reforms: Case study of Pakistani banks. International Research Journal of Finance and Economics, 25, 172-182.

Aigner, D. C. (n.d.). Formulation and estimation of stochastic frontier production function models. Journal of Econometrics, (6), 21-37.

Andrie, A. M. \& dan Cocri, V. (2010). A comparative analysis of the efficiency of Romanian banks. . Romanian Journal of Economic Forecasting, 13(4), 54-75. 
Battese, G. \& Coelli, T. (1995). A model for technical inefficiency effects in a stochastic frontier production function for panel data. Empirical economics, 20(2), 325-332.

Berger, A. N. \& Mester, L. J. (1997). Inside the black box: what explains differences in the efficiencies of financial institutions? Finance and Economics Discussion Series 1997-10, Board of Governors of the Federal Reserve System (U.S.).

Brack, E. \& Jimborean, R. (2010). The cost-efficiency of French banks. MPRA Paper 23471, University Library of Munich, Germany.

Coelli, T. (1998). A multi-stage methodology for the solution of orientated DEA models. Operations Research Letters, 23(3-5), 143-149.

Farrel, M. (1957). The measurement of productive efficiency. Journal of the Royal Statistical Society, (70), 253281.

Hasan, M., Kamil, A., Mustafa, A. \& Baten, M. (2012). Estimating stock market technical efficiency for truncated normal distribution: evidence from Dhaka stock exchange, 7, 532-540.

Kofi, A., Gan, C. \& Hu, B. (2014). Cost Efficiency of Ghana's Banking Industry: A Panel Data Analysis. The International Journal of Business and Finance Research, 8(2), 69-86.

Khalil, Mehmood, B. \& Ahmad, N. (2015). Cost Efficiency of Pakistani Banking Sector. A Stochastic Frontier Analysis. Journal of Commerce, 7(3), 110-126.

Kristo, S. (2013). Efficiency of the Albanian banking system: Traditional approach and Stochastic Frontier Analysis. International Journal of Economic Sciences and Applied Research, (1791-3373).

Koutsomanoli-Filippaki, A., Margaritis, D. \& Staikouras, C. (2009). Efficiency and productivity growth in the banking industry of Central and Eastern Europe. J Bank Finance, 33(3), 557-567.

LR, M. Z. (2004). Economic Efficiency and Frontier Techniques. J Economic Survey, 18(1), 33-77.

Ngan, L. T. (2014). Profit and Cost Efficiency Analysis in Banking Sector. Journal of Knowledge Management, Economics and Information Technology, 4(5), 1-17.

Manlagñit, M. C. (2011). The Economic Effects of Foreign Bank Presence: Evidence from the Philippines. The Economic Effects of Foreign BankJournal of International Money and Finance, 30(6), 1180-1194.

Montgomery, H. H. (2014). Too big to succeed? Banking sector consolidation and efficiency. Journal of International Financial Markets, Institutions and Money, 32, 86-106.

Nazir, M. S. \& Alam, A. (2010). The impact of financial restructuring on the performance of Pakistani banks: a DEA approach. The IUP Journal of Applied Finance, 16(1), 71-86.

Okoire, M. \& Agu, D. (2015). Does Banking Sector Reform Buy Efficiency Of Banking Sector Operations? Evidence from Recent Nigeria's Banking Sector Reforms. Asian Economic and Financial Review, (2), 264-278.

Olaosebikan, B. (2009). Surveying Efficiencies of Nigerian Banks before and after the Minimum Capital Requirement Increase (2009). Honors Projects. Paper 20.

Manlagñit, M. C. (2011). The Economic Effects of Foreign Bank Presence: Evidence from the Philippines. . Journal of International Money and Finance, 30(6), 1180-94.

Meeusen, W. \& van den Broeck, J. (1997). Technical efficiency and dimension of the firm: Some results on the use of frontier production functions. Empirical economics, 2(2), 109-122.

Pruteanu-Podpiera, A., Weill, L. \& Schobert, F. (2008). Banking competition and efficiency: A micro-data analysis on the Czech banking industry. Comparative Economic Studies, 50(2), 253-273.

Rossi, S., Schwaiger, M. \& Winkler, G. (2005). Managerial behavior and cost/profit efficiency in the banking sectors of Central and Eastern European countries. Working Paper 96, Oesterreichische Nationalbank.

Semih Yildirim, H. \& Philippatos, G. (2007). Efficiency of banks: Recent evidence from the transition economies of Europe, 1993-2000. European Journal of Finance, 13(2), 123-143.

Yan, J. (2009). Assessing container operator efficiency with heterogeneous and time-varying production frontiers, 43(1), 172-185. 